\title{
EFEKTIVITAS IZIN GANGGUAN DAN PROBLEMATIKA HUKUMNYA SETELAH PERMENDAGRI 19/2017
}

\author{
Oleh \\ Jimmy Bastian \\ Tomy Michael
}

Fakultas Hukum Universitas 17 Agustus 1945 Surabaya

\begin{abstract}
Any person or entity that wishes to carry out a particular activity which may cause harm, harm, and disruption shall equip themselves with a Disturbance License or Hinder Ordonnantie. The granting of the Nuisance License in general is the authority of the bupati or mayor. In carrying out Nuisance Licenses, the Regional Government may impose a levy called the Distribution License License. The existence of this levy is considered very useful for the Region because it provides a substantial income for the local treasury. However, in early 2017, the Minister of Home Affairs Tjahjo Kumolo revoked the Regulation of the Minister of Home Affairs which regulated the guidelines for the determination of permit disruption in the region. That way, all local regulations governing Nuisance Permissions automatically no longer have a legal basis. So that local government since that time practically no longer able to organize Nuisance Permit. In fact, the authority of the Region to administer the permit is an authority born by Hinder Ordonnantie which is a legally binding regulation of wetgevende organization in colonial Indonesia. Legal research conducted with historical approaches and legislation is intended to describe the authority of the Region in organizing Nuisance Permits.
\end{abstract}

Keywords: hinder ordonnantie, intrusion permission

\section{A.Pendahuluan}

Sebelum berstatus sebagai negara yang berdaulat, Indonesia pernah mengalami masa penjajahan yang cukup lama. Dari tahun 1602 sampai 1800, wilayah Indonesia diduduki dan dikuasi secara ekonomi oleh Verenigde Oostindische Compagnie (VOC) yang merupakan persekutuan dagang dari Belanda. Namun pada tahun 1796, VOC mengalami masa sulit yang menyebabkan persekutuan dagang ini bangkrut. Hal tersebut mengakibatkan VOC harus dinasionalisasi,sehingga pendudukan VOC di Indonesia beralih kepada pemerintah Belanda. Pada masa inilah Indonesia mengalami penjajahan dalam arti yang sebenarmya.Selama masa penjajahan Belanda, berbagai wetten (undangundang) seperti Wetboek van Strafrecht,
Wetboek van Koophande, dan Burgerlijk Wetboek diberlakukan di Indonesia dengan asas konkordansi. ${ }^{1}$ Selain wetten, peraturan perundangan bentukan Pemerintah Hindia Belanda seperti ordonnanties, verordeningen, dan reglementen berlaku dan mengatur berbagai lalu lintas hukum di Indonesia.

Salah satu contoh peraturan perundangan kolonial yang masih berlaku dan mengikat adalah Hinder Ordonnantie ${ }^{2}$ atau Undang-Undang Gangguan.Ordonnantie ini mengatur tentang perizinan yang dipersyaratkan bagi subyek hukum dalam mendirikan bangunan-bangunan tempat bekerja (vide Pasal 1 ayat (1) Hinder Ordonnantie).Pemberian atau penolakan izin tersebut menjadi wewenang kepala daerah 
sebagaimana disebutkan dalam Pasal 1 ayat (3)jo. Pasal 6Hinder Ordonnantie.Melalui izin gangguan, pemerintah daerah diharapkan dapat mengendalikan dan mengawasi kegiatan-kegiatan yang berpotensi menimbulkan bahaya (gevaar), kerugian (schade) atau gangguan (hinder) (vide Pasal 1 ayat (1) angka XX Hinder Ordonnanitie).

Pada tangal 19 April 1984, dalam rangka melaksanakan kebijakan pemerintah dibidang penanaman modal, menteri dalam negerimenetapkan PeraturanMenteri Dalam Negeri Nomor 3 Tahun 1984 Tentang Tata Cara Penyediaan Tanah Dan Pemberian Hak Atas Tanah, Pemberian Izin Bangunan Serta Izin Undang-Undang Gangguan Bagi PerusahaanPerusahaan Yang Mengadakan Penanaman Modal Menurut Undang-Undang Nomor 1 Tahun 1967 Dan Undang-Undang Nomor 6 Tahun 1968 (Permendagri 3/1984). Akan tetapi hanya dalam waktu kurang dari delapan bulan, menteri dalam negeri kemudian merasa perlu mengeluarkan Peraturan Menteri Dalam Negeri Nomor 12 Tahun 1984 Tentang Penyempurnaan Permendagri 3/ 1984 (Permendagri12/1984). Permendagri ini menentukan bahwa ada biaya yang harus dibayar oleh perusahaan yang memohon Izin UndangUndang Gangguan (Vide Lampiran V Permendagri 12/1984).Namun dalam prakteknya ternyata Permendagri 12/1984belum dapat mewujudkan ketertiban dalam hal pungutan biaya Izin UndangUndang Gangguan yang dilakukan oleh pemerintahdaerah. Terdapat ketidakseragaman antar Daerah dalam pungutan Izin UndangUndang Gangguan sehingga menimbulkan kesimpangsiuran dalam pelaksanaanya. Atas dasar pertimbangan tersebut menteri dalam negeri kemudian menetapkanPeraturan Menteri Dalam Negeri Nomor 4 Tahun 1987 Tentang Penertiban Pungutan-Pungutan Dan Jangka Waktu Terhadap Pemberian Izin Undang-Undang Gangguan (Permendagri4/1987). Yang menjadi subyek hukum menurut Pasal 3 ayat (1) Permendagri4/ 1987 adalah Setiap Orang dan Badan Hukum. Dengan kata lain terjadi perluasan subyek hukum dalam Permendagri ini. Selain itu, yang menjadi titik berat dari Permendagri4/1987 adalah bahwa Izin Undang-Undang Gangguan dilekatkan dengan retribusi daerah sebagai salah satu sumber pendapatan daerah. Dalam Pasal 1 huruf h Permendagri 4/1987 menyebutkan: "pungutan adalah pemasukan uang bagi Daerah karena pemberian Izin Tempat Usaha dan Izin Undang-Undang Gangguan (HO) oleh Daerah.

Pada tanggal 23 Oktober 1993, dalam rangka mendorong, memperlancar dan meningkatkan penanaman modal,menteri dalam negeri menetapkan Peraturan Menteri Dalam Negeri Nomor 7 Tahun 1993 Tentang Izin Mendirikan Bangunan Dan Izin Undang-Undang Gangguan Bagi Perusahaan Industri(Permendagri 7/1993). Kurang lebih 16 (enam belas) tahunlamanya Permendagri inidigunakan sebagai pedoman pelaksanaan Izin Undang-Undang Gangguan. Pada medio 2009, Permendagri 7/ 1993 dianggap sudah tidak lagi sesuai dengan kebutuhan pengaturan Izin Gangguan di Indonesia.Atas dasar pertimbangan tersebut, pada tanggal 19 Juni 2009 ditetapkanlahPeraturan Menteri Dalam Negeri Nomor 27 Tahun 2009 Tentang Pedoman Penetapan Izin Gangguan Di Daerah (Permendagri27/2009). Sejak berlakunya Permendagri 27/2009, keberadaan Izin Gangguan pada prakteknya malah menciptakan keadaan yang kurang produktif dilapangan. Sepanjang tahun 2012 misalnya, Izin Gangguan menjadi pelayanan yang paling banyak dikeluhkan masyarakat di kota Bandung. ${ }^{3}$ Dalam website kompasiana.com diberitakan bahwa pelaku dunia usaha mengeluhkan tentang banyak dan berbelitnya persyaratan yang harus dipenuhi untuk mengurus Izin Gangguan. Selain itu, masalah besaran retribusi yang masih belum jelas juga menjadi keluhandikalangan pelaku usaha. ${ }^{4}$ Belum lagi berbagai pendapat yang mengatakan bahwa dengan berlakunya Permendagri 27/2009 terjadi suatu keadaan yang disebut dengan "dobel izin". Hal ini lantaran dimasukkannya kriteria lingkungan sebagai bahan pertimbangan dalam menetapkan Izin Gangguan (Vide Pasal 3 ayat (1) huruf a Permendagri 27/2009). Padahal kriteria lingkungan 
juga menjadi pertimbangan dalam penetapan Izin Lingkungan. ${ }^{5}$ Sebagai respon atas keadaan yang kontrproduktif tersebut, ditetapkanlah Peraturan Menteri Dalam Negeri Nomor 22 Tahun 2016 tentang Perubahan Atas Peraturan Menteri Dalam Negeri Nomor 27 Tahun 2009 Tentang Pedoman Penetapan Izin Gangguan Di Daerah (Permendagri 22/2016). Dengan ditetapkannya Permendagri 22/ 2016, lingkungan tidak lagi menjadi kriteria dalam menetapkan Izin Gangguan. Akan tetapi hanya berselang kurang dari setahun, pada tanggal 29 Maret 2017, menteri dalam negeri menetapkan Peraturan Menteri Dalam Negeri Republik Indonesia Nomor 19 Tahun 2017 Tentang Pencabutan Peraturan Menteri Dalam Negeri Nomor 27 Tahun 2009 Tentang Pedoman Penetapan Izin Gangguan Di Daerah Sebagaimana Telah Diubah Dengan Peraturan Menteri Dalam Negeri Republik Indonesia Nomor 22 Tahun 2016 Tentang Perubahan Atas Peraturan Menteri Dalam Negeri Nomor 27 Tahun 2009 Tentang Pedoman Penetapan Izin Gangguan Di Daerah (Permendagri 19/2017).Permendagri 19/2017 ditetapkan karenapemberian izin gangguan dianggap sudah tidak sesuai perkembangan keadaan, dan tuntutan kemudahan berusaha (konsiderans Menimbang huruf a Permendagri 19/2017).Sejak diundangkannya Permendagri 19/2017 ini, Pemerintah Daerah dianggap tidak lagi berwenang untuk mengeluarkan Izin Gangguan maupun melakukan pungutan retribusi Izin Gangguan.

\section{B. Rumusan Masalah}

Dari fenomena hukum yang diuraikan secara singkat dalam bab sebelumnya, timbul beberapa isu hukum yang terhadapnya patut untuk dilakukan penelitian. Isu-isu hukum tersebut antara lain adalah:

1. Bagaimanakah kedudukan dan keberadaan Hinder Ordonnantie dalam sistem peraturan perundang-undangan di Indonesia?

2. Apakah dengan ditetapkannya Permedagri 19/ 2017 lantas wewenang pemerintah daerah untuk menyelenggarakan Izin Gangguanmenjadi tidak ada lagi?

\section{Metode Penelitan}

Jurnal hukum ini disusun berdasarkan hasil penelitian yang dilakukan dengan pendekatan yuridis normati yaitu didasarkan pada berbagai informasi yang didapatkan dari data sekunderyang diantaranya berupa peraturan perundangundangan, literatur, laman dan jurnal. Selain itu dilakukan pula pendekatan sejarahdan peraturan perundang-undangan. ${ }^{6}$ Sebagai pelengkap, pengumpulan teori-teori dan asas dari berbagai literatur hukum. Isu hukum yang diangkat dalam penelitian ini adalah isu hukum dalam ruang lingkup dogmatik hukum.

\section{Pembahasan}

\section{Sumber Berlakunya Peraturan Perundangan Masa Kolonial}

Hans Kelsen berpandangan bahwa setiap norma hukum menduduki suatu hierarki. Menurut beliau, hierarki norma hukum terdiri atas fundamental norms (norma dasar), General norms (norma umum)danconcrete norms (norma konkret). ${ }^{7}$ Pandangan Hans Kelsen ini banyak dikenal dengan sebutan stuffenbau des rechtstheorie atau Teori Tangga. Menurut teori tersebut semakin tinggi hierarki suatu norma atau peraturan perundang-undangan, maka materi muatannya akan semakin bersifat mendasar dan semakin abstrak karena itu disebut sebagaifundamental norm. Bentuk tertulis dari fundamental norm adalah konstitusi. ${ }^{8}$ Untuk dapat diwujudkan, fundamental normatau konstitusi memerlukan norma atau peraturan perundang-undangan yang prosedur pembuatannya lebih tidak rigit, yaitu general norm. Materi muatan general norm masih bersifat abstrak akan tetapi mengatur kebutuhan hukum faktual yang mengikat untuk umum. Bentuk umum dari general norm ini adalah undang-undang. Atas dasar undang-undang atau general norm, pejabat yang berwenang kemudian dapat mengeluarkan norma konkret yang berbentuk vonnis atau beschikking. Sesuai dengan stuffenbau des rechtstheorie, norma yang hierarkinya lebih rendah harus dibuat atas dasar dan tidak boleh bertentangan dengan norma yang secara hierarkis 
ada diastasnya. Dan norma yang secara hierarkis berada diatasnya menjadi rujukan keberlakuan yuridis norma yang secara hierakis lebih rendah. Dalam Negara Kesatuan Republik Indonesia,yang berperan sebagai norma dasartertulis adalah Undang-Undang Dasar Negara Kesatuan Republik Indonesia Tahun 1945 (selanjutnya disebut UUDNRI).Dalam bahasa yang digunakan oleh Undang-Undang Nomor 12 Tahun 2011 Tentang Pembentukan Peraturan PerundangUndangan (selanjutnya disebut UU 12/2011), UUDNRI adalah hukum dasar dalam peraturan perundang-undangan (Vide Pasal 3 ayat (1) UU 12/2011). Setiap peraturan perundang-undangan dibawah UUDNRI harus menggunakan UUDNRI sebagai sumber hukum (penjelasan Pasal 3 ayat (1) UU 12/2011). Dalam wet, ordonnantie ataupun verordeningen tidak terdapat penyebutan dasar hukum. Bahkan produk-produk hukum kolonial tersebut sudah terbentuk sebelum UUDNRI ditetapkan. Dan dasar hukum yang digunakan adalah Grondwet Belanda meskipun tidak dicantumkan dalam pembentukannya. Kalau begitu apa dasar hukum dari berlakunya peraturanperaturan kolonial tersebut di masa sekarang ini? Jawabannya ada pada Aturan Peralihan UUDNRI Pasal I yang berbunyi: "segala peraturan perundang-undangan yang masih ada tetap berlaku selama belum diadakan yang baru menurut Undang-Undang Dasar ini”.

Aturan Peralihan yang mengatur tentang tetap berlakunya peraturan perundang-undangan (peninggalan kolonial) sudah ada sejak ditetapkannya UUD (Undang-Undang Dasar sebelum perubahan). Alasan dimasukkannya Aturan Peralihan adalah karena pada masa persiapan kemerdekaan, para founding fathers tidak memilki cukup waktu untuk membuat peraturan perundang-undangan yang bersifat umum. Dan karena pada saat itu kemerdekaan dipersiapkan di tengah-tengah peperangan Asia Timur Raya. ${ }^{9}$ Setelah mengalami perubahan sebanyak empat kali, para generasi pemikir bangsa memutuskan untuk tetap mempertahankan Aturan Peralihan dalam batang tubuh UUDNRI. Maksud dan tujuannya masih tetap sama yaitu menjadi dasar hukum bagi keberlakuan peraturan perundangundangan peninggalan Kolonial. Hal ini dapat dibaca dalam pembahasanRapat PAH IBP MPR ke-9 diselenggarakan pada 16 Desember 1999 dengan agenda Dengar Pendapat dengan para Ahli. ${ }^{10}$

Frasa "tetap berlaku selama belum diadakan yang baru" diartikan bahwa tidak boleh ada kekosongan aturan dalam roda pemerintahan Indonesia. Hal ini sebagai konsekuensi logis Pasal 1 ayat (3) UUDNRI yang menegaskan bahwa Indonesia adalah negara hukum. Sehingga normanorma hukum yang ada dalam peraturan-peraturan kolonial itu akan tetap berlaku sampai dengan diakomodirnyanorma-norma hukum tersebut oleh peraturan perundang-undangan yang baru.

\section{Hinder Ordonnantie/Undang-Undang Izin Gangguan}

Dalam van Dale Groot Woorden Boek Der Nederlandse Taal(kamus besar bahasa Bealanda), ordonnantie diartikan sebagaivoorschrift/regel die men moet volgenyang terjemahan bebasnya adalah "peraturan (tertulis) yang harus ditaati".Untuk mengetahui lebih banyak tentang ordonnantie, harus melihat kedalam Grondwet atau undang-undang dasar Belanda pada masa penjajahan (selanjutnya disebut Grondwet). Pada masa itu, Grondwet berlaku diseluruh wilayah Belanda, jadi termasuk juga Indie (sebutan bagi wilayah Indonesia pada masa kolonial). Menurut artikel 61 Grondwet terdapat tiga pembentuk undang-undang yang utama,dua diantaranya berkedudukan di Belanda.Organ yang pertama adalah Mahkota (Ratu) bersama-sama dengan staten-generaal, dan organ yang kedua adalah Mahkota (Ratu) secara mandiri.Keduanya bertindak sebagai Organ legislatif untuk seluruh wilayah Belanda, jadi termasuk juga Indie (Indonesia). Sedangkan organ yang ketiga berkedudukan di Indie (Indonesia) yaituLandvoogd (Gouverneur-Generaal)dan Volksraadsecara bersama-sama,dan Landvoogdsecara mandiri. ${ }^{11}$ Mahkota (Ratu) bersama-sama dengan Staten-Generaal memilki 
wewenang untuk membentuk algemeen bindende regels atau peraturan yang mengikat untuk umum, diantaranya adalah wet. Peraturan yang dibuat oleh Mahkota (Ratu) danStaten-generaal secara bersama-sama berlaku diseluruh wilayah Belanda, termasuk Indie (Indonesia). ${ }^{12}$

Selain Grondwet, ada juga Indische Staatsregeling atau Peraturan Ketatanegaraan Indie(Indonesia)yang merupakan hukum dasar di Indie. Hanya bedanya adalah, kalau Grondwet berlaku diseluruh wilayah kekuasaan Belanda, sedangkan Indische Staatsregeling hanya berlaku di Indie (Indonsia). Menurut artikel 82 Indische Staatsregeling, Landvoogd (GouverneurGeneraal)danVolksraad secara bersama-sama berwenang membentuk ordonnanties. Pengaturan yang dimuat dalam ordonnanties bentukan Gouverneur-Generaal bersama-sama Volksraadadalah peraturan yang mengikat untuk umum berkenanaan dengan kebutuhan dan keadaan asli di Indie(Indonesia) yang belum diatur dan tidak boleh bertentangan dengan Grondwet, wet dan atau Indische Staatsregeling. Jadi pada masa kolonial, ordonnantie secara hierarki berada di bawah wet. Hal tersebut dikarenakan organ yang membentuk wet adalah organ legilatif tertinggi yaitu Mahkota (Ratu) bersama denganStatenGeneraal. Selain itu daya ikat wet lebih luas, karena mengikat untuk seluruh wilayah Belanda termasuk Indie (Indonesia).Sedangkan ordonnantie adalah bentukan organ legislatif yang kewenangannya hanya sebatas wilayah Indie (Indonesia). Akan tetapi, keduanya sama-sama peraturan yang muatan materinyabersifat abstrak dan mengikat umum;dan keduanya dibentuk oleh organ yang memiliki kekuasaan legislatif. Karena itu pasca proklamasi kemerdekaan Indonesia, kedudukanwet dan ordonnantie sudah tidak lagi dianggap berbeda. Logis, karena organ pembentuknya sudah tidak lagi exist di dalam ketatanegaraan Indonesia. Sehingga yang diperhitungkan hanyalah materi muatannya yang sama-sama bersifat abstrak dan mengikat umum. Karena sifat materi muatannya itulah wet dan ordonnantie dipersamakan dengan UndangUndang. Hal dipersamakannya ordonnantie dengan Undang-Undang sesuai Pasal 131 ayat (1) Indische Staatsregelingyang mengatakan "Het burgerlijk en handelsrecht en het strafrecht, zoomede de burgerlijke rechtsvordering en de strafvordering worden, onverminderd de bij of krachtens deze wet aan anderen toegekende strafwetgevende bevoegdheid, geregeld bij ordonnantie......" "yang terjemahannya berbunyi sebagai berikut"Hukum-hukum perdata, dagang dan pidana, begitu pula hukum acara perdata dan pidana, diatur dengan "undang-undang" (ordonansi), dengan tidak mengurangi wewenang yang diberikan oleh atau berdasarkan undang-undang kepada pembentuk perundang-undangan pidana..."

Salah satu contoh ordonnantie yang masih berlaku sampai sekarang adalah Hinder Ordonnantieyaitu ordonnantie yang mengatur tentang Izin Gangguan. Bahkan masih banyak mengundang perhatian pemerintah dan masyarakat Indonesia. Hal tersebut lantaran Izin Gangguan merupakan salah satu dokumen teknis yang dipersyaratkan dalam perizinan tertentu, seperti Izin Mendirikan Bangunan (IMB), Tanda Daftar Usaha Pariwisata(TDUP), dan masih banyak lagi. Hinder Ordonnantie diundangkan pada tanggal 1 Agustus 1926 sebagaimana disempurnakan dan diubah terakhir dengan Staatsblad Tahun 1940 Nomor 450. Dalam judulnya, ordonnantie ini menyebutkan"Nieuwe bepalingen omtrent het oprichten van inrichtingen, welke gevaar, schade of hinder kunnen veroorzaken."Yang terjemahan bebasnya sebagai berikut"Ketentuanketentuan baru tentang pendirian bangunanbangunan yang dapat menyebabkan bahaya, kerusakan atau gangguan."

Dari judul tersebut dapat terlihat bahwa yang menjadi perhatian dalam ordonnantie ini adalah kegiatan pendirian bangunan yang dapat menyebabkan "bahaya, kerusakan atau gangguan".Dalam Pasal 1 ayat (1) Hinder Ordonnantieterdapat dua puluh jenis bangunan yang dilarang untuk dibangun tanpa izin dari pejabat yang berwenang. Sedangkan pada ayat (3) diatur tentang kewenangan Pejabat Daerah Otonom untuk memberikan Izin kepada masyarakat untuk 
dapat menyimpangi larangan sebagaimana dimaksudpada ayat (1).Kewenangan pemberian Izin tersebut diberikan secara eksplisit kepada para kepala daerah yang ketentuannyaberbunyi sebagai berikut:

"De in het eerste lid bedoelde vergunning wordt verleend binnen het ressort van:

a. groepsgemeenschappen, doch buiten het gebied van daarbinnen gelegen stadsgemeenten en gemeenten, door het college van gecommiteerden of, indien zoodanig college niet bestaat, door den voorzitter van den groepsgemeenschapsraad;

b. stadsgemeenten en gemeenten, door het college van burgemeester en wethouders, of, indien zoodanig college niet bestaat, door den burgemeester of, bij gebreke van zoodanigen functionaris, door den voorzitter van den gemeenteraad;

c. buiten de onder $a$ - $b$ bedoelde gebieden door het Hoofd van plaatselijk bestuur".

Yang diterjemahkan sebagai berikut:

"Izin yang tersebut dalam lingkungan wilayah:

a. daerah otonom di luar wflayah kotapraja yang ada dalam lingkungan daerah otonom itu oleh Dewan Harian atau jika tidak ada oleh Ketua Dewan Otonomi,

b. kotapraja oleh majelis walikota dan Dewan Pemerintah Hariannya atau, jika majelis demikian itu tidak ada, oleh walikotanya, dan jika walikota sedang tidak ada, oleh ketua dewannya;

c. di luar wilayah yang tersebut pada a-boleh Kepala Pemerintahan Setempat."

Membaca Pasal 1 Hinder Ordonnantie ini, teringat tulisan Philipus M. Hadjon yang mengatakan "ada izin, kalau norma larangan umum dikaitkan dengan norma umum yang memberikan wewenang kepada suatu organ pemerintahan untuk memberikan persetujuan kepada masyarakat untuk menyimpang dari norma larangan umum itu". ${ }^{14}$

Izin adalah suatu persetujuan dari pejabat yang berwenang untuk dalam keadaan tertentu menyimpang dari ketentuan-ketentuan larangan peraturan perundangan. ${ }^{15}$ Peaturan perundangundangan seringkali memberkan ruang bagi pejabat untuk menilai apakah orang/badan tersebut memenuhi syarat untuk mendapatkan izin.Dalam teori hukum administrasi,kebebasan menilai (beoordelingsvrijheid) ini hadir pada saat undangundang memasangkan kewenangan dengan persyaratan-persyaratan tertentu yang harus dipenuhi untuk bisa sampai kepada pelaksanaannya. ${ }^{16}$ Hinder Ordonnantie memberikan kebebasan menilai (beoordelingsvrijheid) kepada Pejabat untuk mengabulkan atau menolak Izin. Syarat-syarat yang wajib dapat mengakibatkan ditolaknya Izin diatur dalam Pasal 3 dan Pasal 6 ayat (2)Hinder Ordonnantie:

1. menimbulkan bahaya, kerugian, dan / atau gangguan bagi kepentingan, ketertiban, keselamatan, atau kesehatan umum (Vide Pasal 3Hinder Ordonnantie);

2. kerusakan harta milik (Vide Pasal 6 ayat 2 angka romawi II huruf b Hinder Ordonnantie);

3. menjadikan rumah atau bagian-bagian rumah tidak baik atau kurang baik didiami orang(Vide Pasal 6 ayat 2 angka romawi II huruf c angka 1 Hinder Ordonnantie);

4. hal yang merintangi orang menggunakan rumah-rumah sekolah atau ruanganruangan dan bangunan-bangunan untuk perawatan orang sakit atau melakukan ibadat umum(Vide Pasal 6 ayat 2 angka romawi II huruf c angka 1Hinder Ordonnantie);

5. penyebaran kotoran atau penguapan yang memuakkan atau bauyang memuakkan(Vide Pasal 6 ayat 2 angka romawi II huruf c angka 2 Hinder Ordonnantie).

Dari syarat-syarat tersebut diatas, dapat diidentifikasi bahwa motif dari Izin Gangguan adalah untuk mencegah timbulnya keadaankeadaan tertentu yang dapat mengganggu kesehatan, keselematan, ketertiban dan/atau kenyamanan yang dapat mengakibatkan kerugian materiel maupun immaterial bagi orang lain. Untuk 
itu dalam prosesnya, wajib untuk memberitahukan kepada orang-orang yang memiliki, memegang bezit, mengurus dan memakai persil-persil yang berbatasan dengan tanah yang diperuntukkan bagi bangunan yang sedang diproses Izinnya tersebut (Vide Pasal 5 ayat (1) Hinder Ordonnantie). Agar orang-orang yang berpotensi mendapat gangguan dapat dilibatkan dalam pengambilan keputusan Izin Gangguan.

\section{Otonomi Daerah dan Desentralisasi Fiskal}

Indonesia adalah negara kesatuan yang melaksanakan sistem desentralisasi pemerintahan. Dengan kata lain, pemerintah pusat melimpahkan sebagian wewenangnya kepada pemerintah daerah untuk dapat mengatur dan mengurus sendiri urusan pemerintahannya secara mandiri. Landasan konstitusional penyelenggaraan pemerintahan daerah diatur dalam Pasal 18, Pasal 18A, dan Pasal 18B UUDNRI.

Pada tanggal 30 September 2014, Presiden Susilo Bambang Yudhoyono mengesahkan Undang-Undang Nomor 23 Tahun 2014 tentang Pemerintahan Daerah (selanjutnya disebut UU Pemda). Dengan berlakunya UUpemda, urusan pemerintahan diklasifikasikan menjadi urusan pemerintahan absolut, konkuren dan umum (Vide Pasal 9 ayat (1) UU Pemda). Dari ketiga klasifikasi urusan pemerintahan itu, urusan pemerintahan konkuren dibagi antara pemerintah pusat dan pemerintah daerah (Vide Pasal 9 ayat (3) UU Pemda). Untuk dapat menyelenggarakan urusan pemerintahan secara mandiri, pemerintah daerah membutuhkan dana dan biaya; karena itu diatur pula tentang keuangan daerah dalam BAB XI UU Pemda. Untuk dapat memenuhi kebutuhan dana daerah, diaturlah salah satunya tentang pendapatan daerah. Menurut Pasal 285 ayat (1) huruf a UUpemda, pendapatan asli daerah meliputi pajak, retribusi, hasil pengelolaan kekayaan daerah yang dipisahkan dan lain-lain pendapatan asli daerah yang sah. Khusus terkait pendapatan asli daerah pajak dan retribusi, berlaku asas desentralisasi fiskal. Asas ini bermakna bahwa Pemerintah Daerah hanya memiliki hak atau wewenang untuk melakukan pungutan yang jenis dan sebutannya telah ditentukan oleh pembentuk undang-undang. Hal ini diatur dalam Pasal 286 ayat (2) UU Pemda yang menegaskan sebagai berikut:

"Pemerintah Daerah dilarang melakukan pungutan atau dengan sebutan lain di luar yang diatur dalam undang-undang."

Dengan kata lain, pemerintah daerah hanya memilki wewenang untuk memungut pajak dan retribusi, sedangkan wewenang untuk menentukan apa yang boleh dipungut, jenis dan sebutannya tetap berada pada Pemerintah Pusat dalam arti luas.

Dalam bukunya yang berjudul $D e$ Economische Betekenis der Belanstingen, M.J.H. Smeets memberikan definisi pajak:

"Belastingen zijn aan de overhead (volgens normen) verschuldigde, afdwingbare prestaties, zonder dat hiertegenover, in het individuele geval, aanwijsbare tegenprestaties staan. En zij trekken tot dekking van publieke uitgaven."

Terjemahan bebasnya sebagai berikut:

"Pajak adalah prestasi kepada pemerintah yang terhutang melalui norma umum yang dapat dipaksakan, tanpa adanya kontraprestasi individual secara langsung. Dan pajak berfungsi untuk membiayai pengeluaran publik." 17

Selain pajak, yang dapat menjadi sumber pendapatan negara adalah retribusi. Berbeda dengan pajak, pada retribusi si pembayar atau subyek retribusi dapat merasakan secara langsung kontra-prestasi dari retribusi. ${ }^{18}$ Pasal 23 A UUDNRI mengatakan "pajak dan pungutan lain yang bersifat memaksa untuk keperluan negara diatur dengan undangundang". Ketentuan ini mengandung makna bahwa konstitusi menghendaki bahwa pungutan pajak dan pungutan lainnya harus diatur dengan keputusan hukum yang dibentuk oleh Dewan Perwakilan Rakyat bersama-sama dengan Presiden, yang disebut undang-undang. Karena pada sudut pandang tertentu pajak dan pungutan lain merupakan suatu wujud pemaksaan dari negara 
untuk mengambil sebagian hak milik warganya. Pengaturan pajak dan retribusi pada tingkat undang-undang diatur dalam Undang-Undang Nomor 28 Tahun 2009 tentang Pajak Daerah Dan Retribusi Daerah(UU-PDRD). Dalam UU-PDRD dikatakan bahwaRetribusi Daerah adalah pungutan Daerah sebagai pembayaran atas jasa atau pemberian izin tertentu yang khusus disediakan dan/ atau diberikan oleh Pemerintah Daerah untuk kepentingan orang pibadi atau badan (Vide Pasal 1 angka 64). Mengenai jenis-jenis retribusi yang dapat dipungut oleh Daerah, termaktub dalam Pasal 108 UU-PDRD yang membagi obyek dan penggolongan retribusi kedalam Retribusi Jasa Umum, Retribusi Jasa Usaha, dan Retribusi Perizinan Tertentu.

Pasal 141 UU-PDRD menyebutkan yang tergolong dalamRetribusi Perizinan Tertentu, adalah:

a. Retribusi Izin Mendirikan Bangunan;

b. Retribusi Izin Tempat Penjualan Minuman Beralkohol;

c. Retribusi Izin Gangguan;

d. Retribusi Izin Trayek; dan

e. Retribusi Izin Usaha Perikanan.

Dikatakan dalam Pasal 144 ayat (1) bahwa obyek dari retribusi Izin Gangguan adalah pemberian izin tempat usaha/kegiatan kepada orang pribadi atau Badan yang dapat menimbulkan ancaman bahaya, kerugian dan/atau gangguan, termasuk pengawasan dan pengendalian kegiatan usaha secara terus-menerus untuk mencegah terjadinya gangguan ketertiban, keselamatan, atau kesehatan umum, memelihara ketertiban lingkungan, dan memenuhi norma keselamatan dan kesehatan kerja.

Dari rumusan tersebut, dapat dilihat bahwa sebenarnya UU-PDRD menggunakan rumusan Izin Gangguan sebagaimana dimaksud dalam Hinder Ordonnantie.Hakekat undangundangadalahmemuat norma abstrak dan mengikat umum. Hal ini menyebabkan undang-undang tidak jarang memerlukan pengaturan lebih lanjut yang bersifat teknis. Pengaturan tersebut akan didelegasikan kepada peraturan perundangan yang secara hierarkis lebih rendah, misalnya Peraturan
Pemeritah, Peraturan Daerah atau Peraturan Menteri. Proses pendelagasian kewenangan regulasi atau legislasi inilah yang disebut dengan legislative delegation of rule-making power. ${ }^{19}$ Akan tetapi adalah wewenang dari pembentuk undang-undang sebagai pemegang kekuasaan legislasi yang utama untuk menentukan perlu atau tidaknya dan kepada siapa mendelegasikan wewenang mengatur tersebut.Pasal 156 ayat (1) UU-PDRD mengatakan "Retribusi ditetapkan dengan Peraturan Daerah." Hal ini berarti UU-PDRD mendelegasikan wewenang pengaturan kepada peraturan daerah.

\section{Keberadaan Peraturan Menteri Dalam Sistem Perundang-undangan Indonesia}

Didalam negara hukum berlaku asas yang mengatakan bahwa segala gerak-gerik negara haruslah sesuai dengan peraturan perundangundangan. Segala pembatasan terhadap hak-hak dasar warga negara haruslah dituangkan kedalam keputusan hukum bentukanwetgevende organen (organ pembentuk undang-undang). Menurut UU 12/2011Pasal 1 angka 2yang dimaksud dengan Peraturan Perudang-undangan adalah peraturan tertulis yang memuat norma hukum yang mengikat secara umum dan dibentuk atau ditetapkan oleh lembaga negara atau pejabat yang berwenang melalui prosedur yang ditetapkan dalam Peraturan Perundang-undangan.Peraturan perundangundangan di Indonesia dibagi kedalam jenis dan hierarki sebagaimana diatur dalam Pasal 7 ayat (1) UU 12/2011. Pembagian tersebut bermaksudmemberlakukanasas yang melarang peraturan perundang-undangan lebih rendah bertentangan dengan peraturan perundangundangan yang lebih tinggi hierarkinya (Vide Penjelasan Pasal 7 ayat (2) UU 12/2011).Selain pembagian jenis dan hierarki sebagaimana dimaksud dalam Pasal 7 ayat (1) terdapatbeberapaperaturan perundangundanganyang diakui keberadaannya dan mempunyai kekuatan hukum mengikat sepanjang diperintah oleh peraturan perundang-undangan yang lebih tinggi atau dibentuk berdasarkan 
kewenangan; salah satunyaadalah peraturan menteri (Vide Pasal 8 UU 12/2011). Dalam Penjelasan Pasal 8 UU 12/2011 dikatakan bahwa yang dimaksud dengan Peraturan Menteriadalah peraturan yang ditetapkan oleh menteri berdasarkan materi muatan dalam rangka penyelenggaraan urusan tertentu dalam pemerintahan.

Dalam Pasal 7 ayat (1) dan (3) UUDNRI dikatakan bahwa Presiden dibantu oleh menteri dan setiap menteri membidangi urusan tertentu dalam pemerintahan. Untuk memberikan dasar hukum dalam pelaksanaan fungsi dan tugas kementerian negara dibentuklah Undang-Undang Nomor 39 Tahun 2008 tentang Kementerian Negara (UUKN).

Dalam konsep organisasi negara terdapat dua unsur pokok yang saling berkaitan, yaitu organ dan fungsi. Organ adalah bentuk atau wadahnya, sedangkan fungsi adalah isinya; organ adalah status bentuknya, sedangkan fungsi adalah gerakan wadah itu sesuai maksud pembentuknya. ${ }^{20}$ Dikaitkan dengan Pasal 5 ayat (1) UUKN maka terdapat tiga organ, yaitu: menteri luar negri, menteri dalam negeri, dan menteri pertahanan. Sebagai organ, menteri-menteri tersebut memiliki beberapa fungsi, yaitu (Vide Pasal 8 UUKN):

a. perumusan, penetapan, dan pelaksanaan kebijakan di bidangnya;

b. pengelolaan barang milik / kekayaan negara yang menjadi tanggung jawabnya;

c. pengawasan atas pelaksanaan tugas di bidangnya; dan

d. pelaksanaan kegiatan teknis dari pusat sampai ke daerah. (Vide Pasal 8 UUKN)

Menurut Harjono, operasionalisasi dari fungsi-fungsi adalah aspek ke dalam dari tugas yang dimilki organ. Tugas kementerian negera adalah untuk membantu presiden dalam menyelenggarakan urusan pemerintahan (Vide Pasal 7 UUKN). Selain memiliki aspek yang bersifat kedalam, tugas dari suatu organ negara memilki aspek keluar yang disebut dengan bevoegdheid atau wewenang. ${ }^{21}$ Jadi apabila dikaitkan ketentuan Pasal 7 UUKN, dengan frasa "perumusan, penetapan kebijakan" sebagaimana disebut dalam Pasal 8 hurufa UUKN juncto frasa "pelaksanaan kegiatan teknis dari pusat sampai ke daerah" sebagaimana disebut dalam Pasal 8 huruf d UUKN junctis Pasal 8 ayat (1) UU 12/2011, maka salah satu wewenang menteri adalah membentuk peraturan menteri yang keberadaannya diakui sebagai salah satu jenis peraturan perundangan-undangan yang memilki kekuatan hukum mengikat terkait pelaksanaan kegiatan teknis penyelenggaraan urusan pemerintahan dari pusat sampai ke daerah.

\section{Pelaksanaan Izin Gangguan Tahun 1984 - 1993}

Pada tanggal 19 April 1984, menteri dalam negeri menetapkan Permendagri no. 3/1984 yang salah satunya memberikan pengaturan tentang tata cara pemberian Izin Undang-Undang Gangguan bagi perusahaan penanaman modal. Hanya berselang kurang dari delapan bulan, menteri dalam negeri memutuskan untuk mengadakan pernyempuranan atas Permendagri 3/1984 dengan menetapkan Permendagri 12/ 1984. Yang patut menjadi perhatian dalam Permendagri 12/1984 ini adalah dasar-dasar hukum yang dipergunakan. Dalam konsideran Mengingatnya, Hinder Ordonnantie atau UndangUndang Gangguan tidak dicantumkan sebagai salah satu dasar hukum. Hal ini tidak lah sesuai dengan kaidah pembentukan peraturan perundangan di Indonesia. Karena Izin UndangUndang Gangguan adalah instrumen perizinan yang dilahirkan oleh Hinder Ordonnantie atau Undag-Undang Gangguanyang kemudian diatur tata cara pelaksanaannya oleh Permendagri 12/ 1984. Jadi menurut kaidah pembentukan peraturan perundangan di Indonesia, Permendagri 12/1984 ini seyogianya mencantumkan Hinder Ordonnantie atau Undag-Undang Gangguan dalam konsideran Mengingat sebagai salah satu dasar hukumnya.

Pada tahun 1987 pemerintah hendak memaksimalkan pelayanan Izin Undang-Undang Gangguan dengan memperluas subyeknya sekaligus menggandengkannya dengan retribusi daerah. Bagaikan sekali merengkuh dayung dua 
tiga pulau terlewati, dengan ditetapkannya Permendagri 4/1987, melalui pemberian Izin Undang-Undang Gangguan pemerintah dapat meningkatkan pengawasan terhadap dunia usaha sekaligus meningkatkan pendapatan di Daerah.Namun berbeda dengan pendahulunya, Permendagri 4/1987 menyebutkan Hinder Ordonnantie atau Undang-Undang Gangguan dalam konsiderans Mengingatnya. Bahkan dalam menentukan objek yang wajib Izin, Permendagri 4/1987 dalam Pasal 2 ayat (2) merujuk pada Undang-Undang Gangguan, yang berbunyi:

"obyek Izin Undang-Undang Gangguan adalah semua tempat usaha di Daerah yang kegiatan usahanya berdasarkan Pasal 1 ayat (1) Undang-Undang Gangguan Stbl Tahun 1926 No. 26 jo. Stbl Tahun 1940 No. 14 dan 450."

Dalam perkembangannya, menteri dalam negeri mengeluarkan beberapa peraturan yang mengatur tentang Izin Undang-Undang Gangguan, yang diantaranya:

1. Pemendagri 5/1992,

2. Permendagri $7 / 1992$,

3. Permendagri $7 / 1993$ yang mencabut Pemendagri 5/1992 dan Permendagri 7/1992.

Yang perlu menjadi perhatian adalah bahwa Permendagri 7/1993 adalah peraturan menteri dalam negeri terakhir yang masih menempatkan Hinder Ordonnantie atau UndangUndang Gangguan dalam konsiderans "Mengingat"nya. Berbagai peraturan menteri dalam negeri terkait izin gangguan yang ditetapkan setelah Permendagri ini tidak menyebutkan Hinder Ordonnantie atau Undang-Undang Gangguan sebagai landasan yuridisnya. Padahal fungsi peraturan menteri adalah untuk menyelenggarakan pengaturan secara umum dalam rangka penyelenggaraan kekuasaan pemerintahan dibidangnya. ${ }^{22}$ Dengan kata lain, peraturan menteri hanyalah mengatur lebih lanjut hal-hal yang bersifat teknis dalam kapasitasnya sebagai lembaga eksekutif. ${ }^{23}$ Dikaitkan dengan izin gangguan berarti peraturan menteri dalam negeri hanyalah mengatur pelaksanaan ketentuan dari Hinder Ordonnantie. dan karena itu seharusnya peraturan menteri dalam negeri terkait izin gangguan menempatkan Hinder Ordonnantie sebagai landasan yuridisnya.

\section{Pelaksanaan Izin Gangguan2009 - 2016}

Pada tanggal 19 Juni 2009, menteri dalam negeri mengganti Permendagri 7/1993 dengan Permendagri 27/2009. Penggantian tersebut dirasa perlu dalam rangka menjamin iklim usaha yang kondusifdan kepastian dalam berusaha. Disamping itu,adalah kewajiban pemerintah untuk melindungi kepentingan umum serta memeliharalingkungan hidup. Untuk itu, perlu mengoptimalkanIzin Gangguan sebagai sarana pengendalian, perlindungan, penyederhanaan dan penjaminan kepastian hukum,sehingga diperlukan pedoman penetapan Izin Gangguan yang sesuai dengan perkembangan dan kebutuhan hukum yang ada (Vide konsideran Menimbang Permendagri 27/ 2009). Sebagai catatan, bahwa dengan berlakunya Permendagri 27/2009, nomenklatur "Izin UndangUndang Gangguan" sudah tidak lagi dipakai, dan sebagai gantinya dipergunakan nomenklatur "Izin Gangguan".

Yang dimaksud dengan Gangguan dalam Permendagri 27/2009 adalah perbuatan dan/atau kondisi yang tidak menyenangkan atau mengganggu kesehatan, keselamatan, ketenteraman dan/atau kesejahteraan terhadap kepentingan umum secara terus-menerus (Vide Pasal 1 angka 2). Apabilaseseorang atau suatu badan hendak melakukan kegiatan (usaha) yang berpotensi menimbulkan gangguan, maka orang atau badan tersebut wajib meminta persetujuan dari pejabat yang berwenang. Bentuk dari persetujuan tersebut adalah Izin Gangguan. Dalam Pasal 1 angka 3 diberikandefinisidari Izin Gangguan, yaitu: “... pemberian izin tempat usaha/kegiatan kepada orang pribadi atau badan di lokasi tertentu yang dapat menimbulkan bahaya, kerugian, dan gangguan, tidak termasuk tempat usaha/kegiatan yang telah ditentukan oleh Pemerintah Pusat atau Pemerintah Daerah."

Dari definisi tersebut, terdentifikasi bahwa Izin Gangguan yang dimaksud dalam Permendagri 27/2009 masih mengacu pada Hinder 
Ordonnantie.Persamaan tersebut nampak pada frasa "bahaya, kerugian, dan gangguan" yang merupakan terjemahandari frasa "gevaar, schade, of hinder" dalam Pasal 1 ayat (1) angka romawi XX Hinder Ordonnantie. Hal ini menjadi menarik untuk dibahas karena Hinder Ordonnantie tidak disebut dalamkonsideran "Megingat" Permendagri ini. Padahal menurut kaidah pembentukan peraturan perundang-undangan yang baik, undangundang yang digunakan sebagai rujukan ditempatkan pada konsideran "Mengingat". Mengingat fungsi peraturan menteri hanyalah merupakan peraturan pelaksana dari peraturan perundangan yang lebih tinggi, sehingga wajib menyebutkan peraturan yang lebih tinggi itu sebagai landasan mengikatnya. Dengan ditetapkannya Permedagri ini, kriteria gangguan memilki cakupan yang lebih luas. Dalam Pasal 3 ayat (1) disebutkan bahwa kriteria gangguan dalam penetapan izin terdiri dari: lingkungan,sosial kemasyarakatan, dan ekonomi. Kemudian dijabarkan lebih lanjut bahwa gangguan terhadap lingkungan meliputi gangguan terhadap fungsi tanah, air tanah, sungai, laut, udara dan gangguan yang bersumber dari getaran dan/ atau kebisingan,gangguan terhadap sosial kemasyarakatan meliputi terjadinya ancaman kemerosotan moral dan/atau ketertiban umum,dan gangguan terhadap ekonomi meliputi ancaman terhadap penurunan produksi usaha masyarakat sekitar dan/atau penurunan nilai ekonomi benda tetap dan benda bergerak yang berada di sekitar lokasi usaha (Vide Pasal 3 ayat (2), (3), dan (4) Permendagri 27/2009). Dipandang dari teori perundang-undangan, perluasan kriteria gangguan oleh Permendagri ini adalah tidak sebagaimana mestinya. Dikatakan oleh Jimly Asshiddiqie bahwa pembuatan norma hukum yang bersifat mengikat dan membatasi (hak-hak warga negara) hanya dapat dilakukan atas persetujuan dari warga negara sendiri, yaitu melalui perantaraan wakil mereka di parlemen. ${ }^{25}$ Sedangkan fungsi peraturan dari lembaga eksekutif seperti peraturan menteri adalah untuk mengatur hal-hal teknis sesuai dengan kekuasaannya, yaitu eksekusi atau pelaksanaan. Sehingga, tidak seyogiayanya peraturan yang bersifat teknis membuat norma yang bersifat materiel substantif.

Dalam pelaksanaannya, perluasan kriteria gangguan dari aspek lingkungan hidup malah memunculkan kondisi kontraproduktif dalam iklim dunia usaha. Karena sejak berlakunya UndangUndang Nomor 32 Tahun 2009 tentang Perlindungan dan Pengelolaan Lingkungan Hidup (selanjutnya disebut UUPLH), pengusaha wajib memilki Izin Lingkungan yang merupakan persyaratan untuk memperoleh izin usaha dan/atau kegiatan (Vide Pasal 36 ayat (1) jo. Pasal 40 UUPLH). Dengan kata lain, untuk dapat melakukan kegiatan dan/atau usaha, pengusaha harus memilki dua macam perizinan yaitu Izin Gangguan dan Izin Lingkungan yang pada hakekatnya adalah sama. Karena baik Izin Gangguan maupun Izin Lingkungan sama-sama menggunakan aspek lingkungan sebagai dasar pertimbangannya.Karena itulah pada tanggal 28 April 2016 menteri dalam negeri Tjahjo Kumolo menetetapkan Permendagri22/2016 tentang perubahan atas Permendagri 27/2009. Konsideran "Menimbang" dari Permendagri 22/2016 iniberbunyi:

"bahwa Permendagri 27/2009 perlu disesuaikan dengan perkembangan peraturan perundang-undangan guna menjamin iklim usaha yang kondusif, kepastian berusaha, dan melindungi kepentingan umum"

Frasa "memelihara lingkungan hidup" yang mulanya disebutkan dalam konsideran "Menimbang" Permendagri 27/2009, tidak lagi dicantumkan dalam konsiderans "Menimbang" Permendagri22/2016. Dengan membaca konsiderans "Menimbang" bisa kita dapatkan gambaran tentang isi pokok yang hendak diatur dalam suatu peraturan perundangundangan. ${ }^{26}$ Karenakonsiderans "Menimbang" memuat uraian singkat mengenai pokok pikiran yang menjadi pertimbangan dan alasan pembentukan peraturan perundang-undangan tersebut (Lampiran II Nomor 18 UU 12/2011).

Pasal I ayat 1 Permendagri 22/2016 mengatur tentang dihapusnya ketentuan Pasal 3 ayat (1) huruf 
a dan ayat (2) Permendagri 27/2009, sehingga Pasal 3 berbunyi sebagai berikut:

"Kriteria gangguan dalam penetapan izin terdiri dari:

a. dihapus;

b. sosial kemasyarakatan; dan

c. ekonomi."

Sehubungan dengan dihapusnya ketentuan tersebut, sejak tanggal 2 Mei 2016, yang menjadi dasar pertimbangan dalam menetapkan Izin Gangguan adalah bahaya, kerugian, dan gangguan yang meliputi gangguan terhadap sosial kemasyarakatan dan gangguan terhadap ekonomi (Vide Pasal 1 angka 3 Permendagri 27/2009 jo. Pasal 3 Permendagri 22/2016). Selain Pasal 3, ketentuan Pasal 14 dan Pasal 19 ayat (2) huruf b juga mengalami perubahan. Sedangkan selebihnya, penetapan Izin Gangguan masih berpedoman pada Permendagri 27/2009.

Dalam hukum perizinan, hanya pejabat yang berwenang yang boleh menerbitkan atau menolak izin. Dan kewenangan tersebut haruslah berdasarkan pada peraturan perundangundangan. ${ }^{27}$ Berdasarkan Pasal 7 Permendagri 27/ 2009, wewenang Izin Gangguan ada pada bupati atau walikota. Khusus untuk Pemerintah Provinsi DKI Jakarta, pemberian izin merupakan kewenangan Gubernur (Vide Pasal 7 ayat (2) Permendagri 27/2009). Izin Gangguan berlaku selama orang/badan masih melakukan usahanya (Vide Pasal 15 Permendagri 27/2009).

Pada saat Permendagri 27/2009 ditetapkan, undang-undang yang mengatur tentang pemerintahan daerah adalah Undang-Undang Nomor 32 Tahun 2004 tentang Pemerintahan Daerah (selanjutnya disebut UU 32/2004). Dalam Pasal 157, dikatakan bahwa sumber pendapatan daerah terdiri atas pendapatan asli daerah, dana perimbangan, dan lain-lain pendapatan daerah yang sah. Pendapatan asli daerah yang dalam UU 32/2004 disingkat dengan PAD, salah satunya bersumber dari retribusi daerah (Vide Pasal 157 huruf a angka 2). Sedangkan undang-undang terkait retribusi daerah yang menjadi acuan Permendagri 27/2009 adalah Undang-Undang Nomor 18 Tahun 1997 tentang Pajak Daerah Dan
Retribusi Daerah sebagaimana telah diubah dengan Undang-Undang Nomor 34 Tahun 2000 tentang Perubahan Atas Undang-Undang Nomor 18 Tahun 1997 tentang Pajak Daerah dan Retribusi Daerah (selanjutnya disebut UU 18/1997). Dalam UU 18/1997 yang menjadi obyek dari retribusi adalah jasa umum, jasa usaha, dan perizinan tertentu, yang kemudian digolongkan menjadi retribusi jasa umum, retribusi jasa usaha, dan retribusi perizinan tertentu (Pasal 18 ayat [1] dan [2\}). Dalam Pasal 18 ayat (3) UU 18/1997 dikatakan bahwa:

"jenis-jenis retribusi yang termasuk golongan Retribusi Jasa Umum, Retribusi Jasa Usaha dan Retribusi Perizinan Tertentu sebagaimana dimaksud pada ayat (2) ditetapkan dengan Peraturan Pemerintah."

Pasal 5 ayat (2) UUDNRI memberikan kewenangan atributif kepada Presiden untuk menetapkan peraturan pemerintah untuk menjalankan undang-undang sebagaimana mestinya. Dalam literatur, undang-undang sering disebut wet in formele zin atau undang-undang dalam arti formil. Disebut wet in formele zin karena dibentuk oleh pemerintah bersama-sama dengan parlemen sesuai dengan prosedur sebagaimana diatur dalam konstitusi. ${ }^{28}$ Pemerintah bersama dengan parlemen memilki wewenang sebagai wetgevende orgaan (lembaga pembentuk undang-undang). Dan materi muatan undangundang bentukan wetgevende orgaan bersifat umum dan abstrak. Karena itu, sering kali suatu undang-undang memerintahakan kepada lembaga eksekutif untuk menetapkan peraturan yang lebih bersifat teknis sebagai peraturan pelaksana (delegated legislation). ${ }^{29}$

Peraturan Pemerintah Nomor 66 Tahun 2001 tentang Retribusi Daerah (PP 66/2001) merupakan subordinate legislation atau peraturan pelaksana dari Pasal 18 ayat (3) UU 18/ 1997.Dalam Pasal 4 ayat (2) PP 66/2001 dikatakan bahwa jenis-jenis retribusi perizinan tertentu adalah retribusi izin mendirikan bangunan, retribusi izin tempat penjualan minuman beralkohol, retribusi izin gangguan, dan retribusi izin trayek. 
Sebagai catatan yang perlu diperhaitkan adalah, baik dalam UU 32/2004, UU 18/1997, maupun dalam PP 66/2001 yang notabene merupakan landasan yuridis dari Permendagri 27/2009, tidak terdapat ketentuan tentang perintah pembentukan subordinate legislation dalam bentuk peraturan menteri.Bahkan dalam UU 18/1997 Pasal 24 jo. PP 66/2001 Pasal 12 ditegaskan bahwa tata cara pemungutan retribusi ditetapkan dengan peraturan daerah.

Hal yang sama berlaku pada Permendagri 22/2016.Peraturan perundang-undangan yang ditempatkan dalam konsiderans "Mengingat"nya juga tidak memuat ketentuan tentang perintah pembentukan delegated legislation dalam bentuk peraturan menteri. Memang perlu diingat juga bahwa dalam negara hukum berlaku asas freies ermessen atau beleidsvrijheid yang artinya bahwa pejabat pemerintah mempunyai wewenang untuk melakukan perbuatan hukum meskipun undangundang tidak memerintahkannya. Pasal 8 ayat (2) UU 12/2011 dapat ditafsirkan mengakomodir asas freies ermessenyang mengatakan"Peraturan Perundang-undangan sebagaimana dimaksud pada ayat (1) diakui keberadaannya dan mempunyai kekuatan hukum mengikat sepanjang diperintahkan oleh Peraturan Perundang-undangan yang lebih tinggi atau dibentuk berdasarkan kewenangan. ”Jadi suatu peraturan menteri tidak hanya dibentuk atas perintah dari perundang-undangan yang lebih tinggi, tetapi juga dapat dibentuk atas dasar wewenang. Dalam UU Pemda Pasal 1 angka 44 dikatakan "Menteri adalah menteri yang menyelenggarakan urusan pemerintahan dalam negeri." Jadi menteri yang berwenang dalam urusan pemerintahan daerah adalah Menteri Dalam Negeri. Jadi apabila ditafsirkan menggunakan asas freies ermessen dihubungkan dengan Pasal 17 ayat (3) UUDNRIjo. Pasal 8 ayat (2) UU 12/2011 jo. Pasal 1 angka 44 UU Pemda, maka kehadiran Permendagri 27/2009 sebagaimana telah diubah dengan Permendagri 22/ 2016 dapat diakui keberadaannya dan memilki kekuatan hukum yang mengikat.

\section{Pencabutan Izin Gangguan}

Pada tanggal 29 Maret 2017, Menteri Dalam Negeri melalui Peraturan Menteri Dalam Negeri Nomor 19 Tahun 2017 mencabut Permendagri 27/2009 dan Permendagri 22/2016. Dalam konsiderans “Menimbang”nyaPermendagri 19/2017 mengakatakan bahwa Pedoman Penetapan Izin Gangguan di Daerah sudah tidak sesuai dengan perkembangan keadaan, dan tuntutan kemudahan berusahadi Indonesia sehingga perlu dicabut. Sejak diundangkannya Permendagri 19/2017, pemerintah daerah dianggap tidak lagi dapat melaksanakan pelayanan Izin Gangguan dan memungut retribusinya. Hal ini didasarkan pada dalil bahwa peraturan daerah - peraturan daerah yang mengatur tentang Izin Gangguan dan retribusinya mengacu pada Permendagri 27/2009 dan Permendagri 22/2016 sebagai dasar hukum. Dengan kata lain peraturan daerah - peraturan daerah tersebut tidak lagi memilki landasan hukum. Padahal Izin Gangguan adalah perizinan yang penyelenggaraanya didelegasikan langsung kepada pemerintah daerah. Izin Gangguan diatur dalam Hinder Ordonnantie yang diundangkan pada tanggal 1 Agustus 1926 sebagaimana diubah terakhir dengan Staatsblad1940-450, yangdalam Pasal 1 ayat (3)dikatakan:

"Izin yang tersebut dalam lingkungan wilayah:

a. daerah otonom di luar wflayah kotapraja yang ada dalam lingkungan daerah otonom itu oleh Dewan Harian atau jika tidak ada oleh Ketua Dewan Otonomi;

b. kotapraja oleh majelis walikota dan Dewan Pemerintah Hariannya atau, jika majelis demikian itu tidak ada, oleh walikotanya, dan jika walikota sedang tidak ada, oleh ketua dewannya;

c. di luar wilayah yang tersebut pada a-b oleh Kepala Pemerintahan Setempat (Ayat 3 pasal 1 ini disesuaikan dengan susunan pemerintahan dewasa ini). (Ayat 3 pasal ini disesuaikan dengan susunan pemerintahan dewasa ini dengan demikian di sini d dan e dihapuskan)."

Dari ketentuan diatas bahwa Hinder Ordonnantie mendelegasikan wewenang Izin Gangguan kepada tiga pejabat pemerintah daerah, yaitu Dewan Harian atau Ketua Dewan Otonom 
bagi Daerah Otonom diluar wilayah Kotapraja, Walikota atau Ketua Dewan Walikota bagi Kotapraja, dan Kepala Pemerintahan Setempat bagi wilayah diluar Daerah Otonom atau Kotapraja. Ketentuan-ketentuan dalam Hinder Ordonnantie sebagian besar merupakan ketentuan yang bersifat teknis; misalnya seperti Pasal 4 yang mengatur tentang dokumen pelengkap permohonan Izin, Pasal 5 tentang kewajiban pejabat untuk mengumumkan permohonan Izin kepada pihak-pihak terkait dan siapa saja pihakpihak itu, Pasal 6 tentang kondisi-kondisi yang dapat menyebabkan ditolaknya Izin, Pasal 8 tentang isi Izin, jangka waktu Izin, pencabutan Izin, dan seterusnya. Karena itu ordonnantie ini tidak memerintahkan ataupun memerlukan subordinate legislation, karena bisa langsung dilaksanakan, mengingat ketentuan-ketentuannya yang bersifat teknis.

Hinder Ordonnantie merupakan produk hukum bentukan pemerintah kolonial yang sudah ada sebelum Indonesia memilki konstitusi. Lalu apakah kemudian Hinder Ordonnantie ini masih berlaku?

Setelah memproklamasikan dirinya merdeka, Indonesia menetapkan UUD sebagai konstitusinya. UUD merupakan produk hukum yang dibuat ditengah-tengah keadaan perang Asia Timur Raya. Hal ini dapat dilihat dalam penjelasan Soepomo dalam Rapat Besar BPUPKI pada tanggal 15 Juli 1945:

"Paduka Tuan Ketua, undang-undang dasar yang dirancangkan oleh Panitia ini baru dapat dijalankan dengan seluasluasnya sesudah habis perang. Jikalau kita mendapat kemerdekaan dalam saat peperangan ini,memang inilah yang kita harapkan. Maka sudah tentu undangundang dasar ini tidak bisa dengan seketika dijalankan. Suasana perang meminta perhatian istimewa, suasana perang menghendaki aturan-aturan istimewa, agar pemerintah dapat berjalan dengan lekas dan cepat. Keadaan perang tidak boleh adanya peraturan yang mengharuskan pemerintah setiap-tiap waktu bermusyawarat dengan Badan Perwakilan Rakyat untuk mengambil tindakan-tindakan yang harus lekas dijalankan....". ${ }^{30}$

Di tengah keadaan perang itu, para pendiri bangsa tidak memilki banyak waktu untuk membentuk peraturan perundang-undangan yang cukup untuk menjalankan roda pemerintahan sebagaimana mestinya. Untuk menghindari kekosongan hukum maka berbagai peraturan perundangan yang telah ada harus tetap dinyatakan berlaku. Hal tersebut dilakukan dengan menyisipkan Aturan Peralihandalam UUD, yang mengatakan:

Pasal II

Segala badan negara dan peraturan yang ada masih langsung berlaku, selama belum diadakan yang baru menurut UndangUndang Dasar ini.

Atas dasar Pasal II Aturan Peralihan segala peraturan perundangan peninggalan masa kolonial masih tetap berlaku (selama belum diadakan yang baru).

Pada tahun 1999 sampai dengan 2002, konstitusi mengalami perubahan sebanyak empat kali. Dalam empat kali perubahan tersebut tidak sedikit ketentuan yang dihilangkan. Akan tetapi Aturan Peralihan diputuskan untuk tetap diberi tempat dalam konstitusi. Hanya saja ketentuan ini mengalami sedikit perubahan pada penomoran pasal dan ketentuannya, sehingga berbunyi: ATURAN PERALIHAN Pasal I

Segala peraturan perundang-undangan yang ada masih tetap berlaku selama belum diadakan yang baru menurut Undang-Undang Dasarini.

Jadi ketentuan ATURAN PERALIHAN Pasal I UUDNRI inilah yang menjadi landasan yuridis keberlakuan peraturan perundangan kolonial termasuk Hinder Ordonnanite sampai sekarang ini(selama belum diadakan yang baru).

Dalam negara hukum, terdapat normenhiërarchie beginsel atau asas hierarki 
norma. Asas tersebut bermakna bahwa kekuatan hukum peraturan perundang-undangan itu sifatnya berjenjang. Masih berhubugan dengan asas hierarki norma adalah asas contrario actus yang bermakna bahwa suatu peraturan perundangan hanya bisa diubah atau dicabut oleh peraturan perundangan dari jenjang yang sama. ${ }^{31}$ Maria Farida Indrati dalam bukunya mengatakan "bagi Ordonnantie yang masih berlaku di Indonesia, kedudukannya disetingkatkan dengan undangundang." ${ }^{2}$ Dari penelusuran terhadap norma yang setingkat undang-undang, tidak terdapat pencabutan ataupun perubahan atas Hinder Ordonnantie. Dengan kata lain, Hinder Ordonnantie masih tetap berlaku.

Terkait retribusi izin gangguan, mengacu UU-PDRD. UU-PDRD adalah undang-undang yang saat ini berlaku dibidang pajak dan retribusi yang juga menjadi landasan yuridis dari Permendagri 22/2016 sebagaimana disebutkan dalam kosiderans "Mengingat"nya. Seperti yang penulis bahas pada pembahasan sebelumnya, bahwa UU-PDRD tidak memuat ketentuan yang memerintahkanperaturan menteri untuk mengatur lebih lanjut tentang tata cara Retribusi Izin Gangguan. Bahkan dalam Pasal 160 ayat (5)UUPDRD dikatakan "Tata cara pelaksanaan pemungutan Retribusi ditetapkan dengan Peraturan Kepala Daerah. "Sehingga wewenang pemerintah daerah dalam memungut retribusi izin gangguan bukan berdasarkan Permendagri 22/ 2016, melainkan langsung berlandaskan pada UU-PDRD. Sehingga selama ketentuan UUPDRD tentang retribusi masih belum diubah dan berlaku maka wewenang daerah untuk memungut retribusi izin gangguan pada dasarnya masih tetap ada.

\section{C.Penutup \\ 1. Kesimpulan}

Dari pembahasan diatas didapatkan kesimpulan bahwa Hinder Ordonnantie setingkat dengan undang-undangsehingga hadirnya Permendagri 19/2017 tidak menyebabkan wewenang Daerah untuk menyelenggarakan Izin Gangguan menjadi hapus.

\section{Saran}

Apabila Pemerintah Pusat menilai Izin Gangguan beserta Retribusinya tidak lagi sesuai kebutuhan masyarakat sehingga perlu dicabut, maka instrumen pencabutannya harus setingkat undang-undang. Misalnya dengan Peraturan Pemerintah Pengganti Undang-Undang Presiden dapat mencabut Hinder Ordonnantie dan menghapus Retribusi Izin Gangguan dalam UUPDRD.

Bagi Daerah yang menghendaki pelaksanaan Izin Gangguan pasca diundangkannya Permendagri 19/2017,dapatmenetapkan Peraturan Daerah terkait Izin Gangguan yang baru dengan mengacu pada Hinder Ordonnantie dan UU-PDRD sebagai dasar hukumnya.Karena itu, pada kesempatan ini para pelaku usaha perlu menggunakan hak partisipasinya dalam hal Pemerintah di Daerahnya menyusun Perda Izin Gangguan yang baru. Partisipasi tersebut dapat dilakukan dalam bentuk penyampaian aspirasi dan/ atau rapat dengar pendapat umum. ${ }^{33}$

\section{Daftar Pustaka}

Asshiddiqie, Jimly, 2006, Perihal UndangUndang, Jakarta, Sekretariat Jenderal Dan Kepaniteraan Mahkamah Konstitusi RI. ,2006, Perkembangan dan Konsolidasi Lembaga Negara Pasca Reformasi, Jakarta, Sekretariat Jenderal Dan Kepaniteraan Mahkamah Konstitusi RI. ,2006, Pengantar Hukum Tata Negara Jilid II, Jakarta, Sekretariat Jenderal dan Kepaniteraan Mahkamah Konstitusi RI.

Bergamin, R.J.B, 2003, Van Apeldoorn's Inleiding Tot De Studie Van Het Nederlandse Recht, Deventer, Kluwer.

Brotodihardjo, Raden Santoso, 1991,Pengantar Ilmu Hukum Pajak, Bandung,Eresco. Hadjon, Philipus Mandiri, 1993, Pengantar Hukum Perizinan, Surabaya, Yuridika. 
Marzuki, Peter Mahmud. 2015,Penelitian Hukum, Edisi Revisi Cetakan Ke-10, Jakarta, Kencana Prenada Media Grup.

Soeprapto, Maria Farida Indrati, 2007,Ilmu Perundang-undangan, Yogyakarta, Kanisius. Subekti, 2002, Pokok-pokok Hukum Perdata, Jakarta, Intermasa.

Westra, Herman, 1927,De NederlandschIndische Staatsregeling, s-Gravenhage, Martinus Nijhof.

ten Berge, Joanes Benedictus Joseph Maria, 2001, Bestuuren Door De Overheid, Deventer, W.E.J. Tjeenk Willink en G.J. Wiarda Instituut.

Naskah Komprehensif Perubahan UndagUndang Dasar Negara Republik Indonesia Tahun 1945, Edisi Revisi,2010, Jakarta, Sekreteariat Jenderal Dan Kepaniteraan Mahkamah Konstitusi.

De Wetboeken, Wetten En Verordeningen, Benevens De Grondwet Van De Republiek Indonesië, 1989, Jakarta, Ichtiar Baru-Van Hoeve.

Himpunan Peraturan Perundang-Undangan Republik Indonesia, 1989, Jakarta, Intermasa.

Website Pikiran Rakyat, dalam daring

https://WWW.pikiran-rakyat.com/bandung-raya/ 2013/01/17/219368/keluhan-masyarakatlayanan-izin-gangguan-kelamaan, tanggal akses 30 Januari 2018.

Yayan Sakti, dalam daring

https://WWW.kompasiana.com/yayan_sakti/ hinder-ordonantie-ho-jadi-hantu-seramkantor-perijinan, tanggal akses 30 Januari 2018. 